\title{
The Relationship between Spiritual Intelligence and Transformational Leadership Style among Student Leaders
}

\author{
Samantha Yee Min $\operatorname{Tan}^{1}$, Susan Tee Suan $\mathrm{Chin}^{1}$, Afzaal H. Seyal ${ }^{2}$, \\ Jian Ai Yeow ${ }^{1}$ and Khong Sin Tan ${ }^{1}$ \\ ${ }^{1}$ Multimedia University, Malacca, Malaysia
}

${ }^{2}$ Postgraduate Studies \& Research, Institute of Tech. Brunei

Correspondence should be addressed to: Samantha Yee Min Tan; samanthatym@hotmail.com

Received 28 January 2013; Accepted 18 May 2013; Published 30 September 2013

Academic Editor: Shastri L Nimmagadda

Copyright (C 2013 Samantha Yee Min Tan, Susan Tee Suan Chin, Afzaal H. Seyal, Jian Ai Yeow and Khong Sin Tan. Distributed under Creative Commons CC-BY 3.0

\begin{abstract}
The purpose of this study is to analyse the influence of Spiritual Intelligence to transformational leadership style displayed by student leaders. Students are the future leaders in organizations, be it in the public or the private sector. During the years spent at the institutions of higher learning, students will be able to learn and experience many types of leadership either through their own capacity as the leader or as a team member. A total of 200 questionnaires were distributed to students. The students that participated in this study were from many parts of the world. It was found that correlation exist between Spiritual Intelligence and Transformational Leadership style displayed by the students. However, most of their coefficients indicate a moderate degree of strength. It is through group activities that students develop their leadership skills. As such, coordinators of these activities need to guide and nurture the leadership skills of the students.
\end{abstract}

Keywords: Leadership style, Transformational Leadership style, Spiritual Intelligence.

\section{Introduction}

Student leadership cannot be denied is the most beneficial extracurricular activity a student can perform and experience in their studies (IPlan 2011). Although there are no grades and zero credits hours to be earned, the experience gained from the leadership roles played is invaluable. According to
Dougherty (2011), that there is very little research with empirical support that relates leadership to Spiritual Intelligence. It is even harder to search for existing research on students and spirituality. Spiritual Intelligence is defined as the ability of one to apply and reflect spiritual resources and qualities to enhance daily activities and well being (Amran, 2007). Leadership is a topic

Cite this Article as: Samantha Yee Min Tan, Susan Tee Suan Chin, Afzaal H. Seyal, Jian Ai Yeow and Khong Sin Ta (2013), "The Relationship between Spiritual Intelligence and Transformational Leadership Style among Student Leaders," Journal of Southeast Asian Research, Vol. 2013 (2013), Article ID 319474, DOI: $10.5171 / 2013.319474$ 
that has created much buzz since the 1970's. There are so many different dimensions that are proposed by famous researchers such as Burns (1978) and Bass (1985) that are still being used till this day. It is no doubt the importance and also the significance of leadership in the society that it is such a popular topic. However, in this research, a new blood is included, Spiritual Intelligence. Spiritual Intelligence is a considerable new topic that have yet gain full acceptance in the society as there are much argument of the reliability of it. But yet, in the psychology world, there are no fixation- new changes, problems, dimension, angle, mindset, visions and combinations. The purpose of this study is to examine the relationship between Spiritual Intelligence and the Transformational leadership styles displayed by the student leaders.

\section{Literature Review}

\section{Transformational Leadership}

Bass (1999) defined Transformational Leadership as leaders who heighten morale, motivation and morals of their followers. Bass (1999) also justified that Transformational Leaders are those who creates an independent and challenging work environment increases the job satisfaction of their followers. Bass (1999) identified three ways in which leaders can transform their followers (transformationalleadership.net, 2007): (i) create high awareness of task importance and values, (ii) looking into the big picture: focus on group or organizational goals rather than self interest and (iii) discovering followers' higher-order needs. Caldwell, et al (2011) defined Transformational Leadership as a highly ethical standard of leadership that advantages the respect of employees and society.

It is important that trust exist in leadership for the willingness to pinpoint with the organization and learn its values and the emergence in the workforce of superior organizational citizenship behaviour (altruism, conscientiousness, sportsmanship, courtesy, and civic virtues) (Podsakoff, et al. 1990). Pagan (2008) added that Transformational Leaders create something new from something old. Transformational Leadership is the ability of defining the reality of others. Transformational Leaders spend time listening, summarizing, coordinating and guiding what that is said, making key interventions and visualizing the idea, values, image to those involved in order to make sense of the situation they are facing (Morgan, 1997).

The four characteristics of Transformational Leadership described by Avolio, Waldman, and Yammarino (1991) are idealized influence or charisma, inspirational motivation, intellectual stimulation and lastly, individualized consideration or individualized attention. Idealized influence is the ability of Transformational Leaders to visualize a desirable future, plan meticulously how to reach it, be the role model, expect high performance standard and also shows determination and confidence to their followers (Bass, 1999). Idealized influence can evoke strong follower emotions and acceptance with the leader (Bass, 1999; Yukl, 2006). Banerji and Krishnan (2000) realized that these leaders are usually known as charismatic leaders to their followers. According to Bass (1999), charismatic leaders have firm beliefs and opinions, takes responsibility and influence followers on an emotional level. Genuine trust based on solid moral and ethical foundation must be form leader and followers.

Inspirational motivation is the ability of a leader to inspire follower through tactfully translating an appealing future. It is how leaders challenge followers by setting high requirement, communicates future goals and gives purpose to task distributed Bass (1999). Leaders with inspirational motivation have to be equipped with excellence communication skills that allow them to translate their vision into powerful, compelling and persuasive words precisely 
(Yukl, 2006; transformationalleadership.net, 2007). Inspiration motivation drives leaders to stay focus on vision of group despite facing any obstacles (Kent, Crotts, \& Azziz, 2001).

Bass (1999) describes intellectual stimulation as traits of leaders who assist followers to become more innovative and creative. Avolio, Bass and Jung (1999) states that intellectual stimulation is to let followers question the tried and true ways of solving problems by encouraging them to make improvement on those ways. By challenging leader's decision and group processes, innovative thinking is encouraged (Bass and Steidlmeier, 2003).

Transformational Leaders play the role of a mentor by distributing responsibilities to followers, giving them an opportunity to grow and also attain self-actualization through the process of it (Avolio, Bass and Jung, 1999). It was found that individualized consideration plays a positive role in affecting and facilitating team-building efforts (Corrigan and Garman, 1999). Yukl (2006) sees individualized consideration as behaviour of support, encouragement, and guidance to followers. Barnett, McCormick, and Conners (2001) however, described it as the development of interpersonal relationship between leader and followers. Bass and Steidlmeir (2003) stated that it is the relationship of mentoring and couching based on each follower's individual development needs that results the evolution of followers into leaders.

\section{Transactional Leadership}

Bass (1985) defined Transactional Leadership as monitoring and controlling followers through reasonable and financial means. In contrast to Transformational Leadership, Transactional Leadership focuses on short-term goals and daily operation leadership (Podsakoff, et al., 1990). Bass (1985) described it as a passive leadership. Bass and Avolio's (1997) model of Transactional Leadership contains three factor: contingent reward, management-by- exception (active), and management-byexception (passive). Transactional Leadership involves terms exchange relationship between leader and followers in order to meet self-interest goals (Bass, 1999). Bono and Judge (2004) stated contingent rewards as leadership behaviours that focus on the exchange of resources. In this context, leaders give followers tangible or intangible rewards in exchange for their effort and performance. Bass (1999) stated that a leader clarifies direction, set out goals and expectation and rewards followers who achieve them. Basham (2010) defined rewards as salary and benefits, bonuses and other incentives.

Management-by-expectation (active) refers to leaders monitoring progress of followers and leading them to be on track when necessary (Bass and Avolio, 1997; Bass, 1999). Connor (2004) stated that a few action of management by expectation are such as corrective criticism, negative feedback and negative reinforcement. Job evaluation performance is one of the common ways of active management by expectation. Leaders identify problem, propose corrective measurement that can be done and this make prevention on undesired outcome (Connor, 2004).

Management-by-expectation (passive) refers to leaders who take action after a mistake is done (Bass and Avolio, 1997). Bass (1985) introduced laissez-faire, leaders who do not want to take responsibility, under Transactional Leadership. Laissez-faire leadership avoids making decision, or action. They self-remove their authority and are absent when a leader is needed (Bass and Avolio, 1997). Basham (2010) commented that Transactional Leaders control by utilizing output to maintain status quo. The passivity of these leaders leads to the low recognition of contribution, but is the direction of finger pointing when an error occurs. Transactional Leaders focus on short term basis and have no interest in changing the environment or culture. The relationship 
between a Transactional Leader and followers is based on an agreement where both party shares a common goal and expectation (Bass, 1978). The major drawback of this kind of leadership is it does not fulfil the desire for self-actualization (Dollak, 2008).

\section{Spiritual Intelligence}

Intelligence is a skill, an innate potential that can be developed through trainings (Wigglesworth, 2003). As old as it can be, it is a tool used to distinguish an individual from one another and also a predictor of where you stand in a society (Animasahun, 2010). Everyone is born with intelligence, but to differentiate that, tests are being developed. For example, Intelligence Quotient (IQ) test is used to determine logical thinking, cognitive thinking and rule-bound thinking. Meanwhile, Emotional Quotient (EQ) is related to emotive thinking, associative and habit bound thinking (Zohar and Berman, 2001). These tests take account of performance or outward behaviours to determine the level of developed skills (Wigglesworth, 2003).

Wigglesworth (2003) defines spirituality as a belief of "something greater than me", a desire to be connected to humanity creator (Source) or traditionally being personified as God. Spirituality is appears to be in the field of pure consciousness in the Quantum Field. However, Wigglesworth (2003) also emphasizes that spirituality is different from religion. Although religious is one way to be connected to the Source but it is not the only way.

Spiritual Intelligence is out-of-box thinking if compared to Intelligence Quotient or Emotional Quotient. According to Zohar and Berman (2001), Spiritual Intelligence is conceptualized as creativity, in-depth and transformative thinking. It is a mindset that would incorporate duty, understanding, nurturing, and personal transformation into. Zohar and Marshall (2000) referred Spiritual Intelligence as the development of desire and capacity for purpose, vision and values that juggles between reason and emotion, mind and body. It combines interpersonal communication skill and intrapersonal thoughts that surpasses the difference between self and others.

Wigglesworth (2002) and Animasahun (2010) defined Spiritual Intelligence as the ability to conduct oneself with compassion and wisdom while maintaining a peaceful composure under any circumstance. Wigglesworth (2002) placed Spiritual Intelligence at the top of the pyramid in comparison with Physical Intelligence (PQ), Emotional Intelligence (EQ) and Intellectual Intelligence (IQ). Swarup (2010) also stated that Spiritual Intelligence might be the highest form of intelligence based on Howard Gardner's Multiple Intelligence theory.

Zohar (2010) elaborates spiritual capital as wealth, power and influence gained by acting with deep sense of values that serve a higher purpose, express through a faithful life to service. Thus, Spiritual Intelligence is what used to build spiritual capital. It is by understanding what the purpose of life is and be committed to it with the deepest value.

Furthermore, according to Zohar (2010) and Swarup (2010), to provide with more evidence of Spiritual Intelligence, neurologists had proven the existence of an area devoted to spiritual experience within the brain's temporal lobe. It is known as the 'GOD SPOT' that is activated based on one's emotional intensity and activity. Swarup (2010) also commented that to inculcate human awareness and learning, widely using Spiritual Intelligence will contribute to natural and sustainable civilization growth at all levels. It is also helpful in conflict management and maintaining a peaceful society (Animasahun, 2010).

Danah Zohar and Ian Marshall (2000) defined Spiritual Intelligence as a problem solving skill that incorporate one's belief and value into one's actions and decisions, which leads to a meaningful course of action. They 
have listed twelve qualities of Spiritual Intelligence. It includes:

* Self-awareness: Knowing what oneself believes in and gives motivation.

* Spontaneity: Be responsive and adaptive to situations.

* Being vision and value-led: Actions based on belief and values that are deeply rooted.

* Holism: Ability to look into a bigger picture, do not see things as individuals but as a form of patterns, connections, and relationship. Have sense of belonging.

* Compassion: Capabilities to 'feel' and express empathy.

* Celebration of diversity: Value and not isolate the differences in others.

* Field independence: Stay confidence in own ground even if it means to go against others.

* Humility: Have a sense of one's part and position in the world.

* Tendency to ask fundamental "Why?" questions: Have curiosity to get to the bottom of truth.

* Ability to reframe: Have a 'helicopterview' in situation to see the full picture.

* Positive use of adversity: Learn and advance oneself from mistakes, setbacks and suffering.

* Sense of vocation: A sense of responsibility, to give something in return.
Robert Emmons (2000) has defined Spiritual Intelligence as the adaptive use of spiritual information to ease daily problem solving and goal attainment. It is a mechanism to improve the quality of life. He included four characteristic into his Spiritual Intelligence dimension, which are:

a) The capacity to reach beyond normal capacity.

b) The ability to increase degree of spiritual states of consciousness,

c) The ability to capitalize daily activities, events, and relationships with a sense of the devotion.

d) The ability to utilize spiritual resources in daily problem solving.

Frances Vaughan (2002) claimed Spiritual Intelligence as a source related to the inner life of mind and spirit to the outside world. It is the capacity of understanding existential doubts and insight into multiple level of consciousness. It also relates to awareness of spirit as core of a being and the creative life force evolution. Vaughan (2002) described it as beyond individual mental ability. Spiritual Intelligence is an awareness of oneself with all surrounding elements. Cindy Wigglesworth (2006) concluded Spiritual Intelligence as the ability to act with wisdom, and compassion, while staying in equanimity in any circumstances. She further formulated her model of Spiritual Intelligence and consolidates the 21 skills into four quadrants. 
Table 1: The Four Quadrant Model for Spiritual Intelligence Skills

\begin{tabular}{|c|c|}
\hline $\begin{array}{l}\text { Higher Self/Ego self Awareness } \\
\text { Awareness of own worldview } \\
\text { Awareness of life purpose (mission) } \\
\text { Awareness of values hierarchy } \\
\text { Complexity of inner thought } \\
\text { Awareness of Ego self / Higher Self }\end{array}$ & $\begin{array}{l}\text { Universal Awareness } \\
\text { Awareness of interconnectedness of all life } \\
\text { Awareness of worldviews of others } \\
\text { Breadth of time / space perception } \\
\text { Awareness of limitations/power of human } \\
\text { perception } \\
\text { Awareness of Spiritual laws } \\
\text { Experience of transcendent oneness }\end{array}$ \\
\hline $\begin{array}{l}\text { Higher Self/Ego self Mastery } \\
\text { Commitment to spiritual growth } \\
\text { Keeping Higher Self in charge } \\
\text { Living your purpose and values } \\
\text { Sustaining your faith } \\
\text { Seeking guidance from Spirit }\end{array}$ & $\begin{array}{l}\text { Social Mastery / Spiritual Presence } \\
\text { A wise and effective spiritual teacher/mentor } \\
\text { A wise and effective change agent } \\
\text { Makes compassionate and wise decisions } \\
\text { A calming, healing presence } \\
\text { Being aligned with the ebb and flow of life }\end{array}$ \\
\hline
\end{tabular}

Yosi Amran (2007) later identified Spiritual Intelligence as the ability to apply and embrace spiritual resources and qualities to improve daily activities and wellbeing. Amran and Dryer (2008) redefined Spiritual Intelligence as the ability to understand accept and apply the available spiritual resources and qualities to improve daily duties and wellbeing. The seven dimensions from previous study was breakdown and five dimensions remained, namely: Consciousness, Grace, Meaning, Transcendence, and Truth. The following shows the subscales of each dimension.

a) Consciousness: Intuition, Mindfulness, and Synthesis.

b) Grace: Beauty, Discernment, Freedom, Gratitude, Immanence, and Joy.

c) Meaning: Purpose, Service.

d) Transcendence: Higher-self, Holism, Practice, Relatedness, and Sacredness.

e) Truth: Egolessness, Equanimity, Innerwholeness, Openness, Presence, and Trust.

Due to the large variation in definitions of Consciousness, some researchers identified it as an intrinsic value, not a physical object or void. However, in the advancement of neuroscience, Consciousness became more materialistic or physical (Velman, 2009). Theories of Consciousness can be divided into reductive or non-reductive views, but Chalmers (2002) viewed non-reductive views to be more promising. According to Velman (2009), Consciousness can be simply translated as awareness, experience, knowledge or wakefulness. In order to understand what consciousness meant, the phenomenology of it is essential, for example, the root or causes of Consciousness, its functions. In order to identify Consciousness in spiritual intelligence, the three capabilities that Amran (2007) used to define will be adapted: mindfulness, trans-rational knowing and practice. Based on Amran (2007), Consciousness is an established selfknowledge and awareness. He described it as an ability to heighten or move Consciousness, to strike intuition, to combine several points of view so that daily functioning and wellbeing can be enhanced (Amran \& Dryer, 2008).

In the Amran and Dryer's (2008) dimension, three characteristic was added, namely intuition, mindfulness and synthesis. Patton (2003) describes intuition as an immediate reaction towards a situation without logical 
thinking and may often be irrational. However, there are also argument that these reaction comes from the accumulation of experience and education. Sundgren and Styhre (2004) also supported the idea by quoting Henri Bergson's ideology of Intuition as the capability of flexibility thinking and it is very much a part that contributes to sophisticated thinking.

Mindfulness is expressed as understanding oneself and existing with defined purpose and thoughtful, embrace awareness and presence (Amran, 2007). Mindfulness can also be explained as a state of full involvement and attention on present. Mindful people will always be in check with self thoughts and emotions without critiques. Bjurström (2012) spoke of Mindfulness as an important aspect that contributes to quality management. Bjurström (2012) further defined Mindfulness as a need to challenge traditional beliefs and also re-evaluate the processes of consciousness. Amran \& Dryer (2008) listed several Mindfulness characteristics which includes i) Always eager to discover self inadequate; ii) Able to consider from other's point of view in discussion or negotiation; iii) Live with awareness of self limitations; iv) Have the ability to extract self and re-evaluate situations, doing corrective actions; and v) Always in control of self thoughts and feelings.

Synthesis in general is defined as the combination of ideas, beliefs, and styles to form a theory (Oxford Dictionary, n.d.). Amran \& Dryer (2008) defined synthesis with three components: i) the ability to seek for a common ground when path is clouded, ii) the ability to go beyond self limits in order to solve problems, and iii) the ability to stay true to oneself when in times of disturbance.

Amran \& Dryer (2008) categorized Grace into six areas: Beauty, Discernment, Freedom, Gratitude, Immanence and Joy. Reber, Schwarz, \& Winkielman (2004) defined Beauty as a pleasurable experience that comes without a reason to its perceiver and is often objectified. Langlois, et al. (2000) associated Beauty with attractiveness that is contributed by various positive characteristics. Amran \& Dryer (2008) evaluated Beauty through the following i) the ability to appreciate one's hard work, ii) the ability to notice details of one's life and iii) the ability to express oneself truthfully.

Discernment is defined as the wisdom of seeing the truth by looking into inner conscience (Amran, 2007). It is explained as the ability to make good judgment by various dictionaries. Schaefer (2008) defined Discernment as a process of one's effort to balance personal good with the greater good of common goals of the organization. Traüffer, et al. (2010) described Discernment as an ancient Hebraic concept as the power to motivate, pushing individuals (followers) into a purposeful action while affecting their thought, emotions and actions. Amran \& Dryer (2008) defined it with the ability to stand firm to what known to be true to one. Freedom is the ability to be free from environmental pattern, bonds and fear, manifesting bravery, creativity and fun. Hanna (2011) defined Freedom as an independent power of choice. Amran \& Dryer (2008) listed the characteristics of Freedom as the courage to choose what that is right and not to subdue to authorization, popularity or majority. Wood, Froh, \& Geraghty (2010) defined Gratitude as an appreciation of success or abilities to succeed. Meanwhile, Emmons \& McCullough (2003) defined it as a series of behaviour, feeling, moral virtue, and a response to others. Gratitude is also highly related to one's well being (Wood, et al., 2010). Amran \& Dryer (2008) categorized it as the ability to cherish and be grateful for the positive matters that happen in life.

Immanence is related to closeness of relationship where people feel united and also stand as an identity (Willsey, 2003). McDowell (1995) suggested that Immanence is very much related to god and is also 
frequently compared with Transcendence. He described Immanence as an existence and presence of a physical entity. Amran \& Dryer (2008) defined it as the ability to be fully connected to the presence activity where one is aware of even the most insignificant daily routines and is able to see life as a whole. Joy refers to an emotion of happiness (Oxford Dictionary, n.d). Amran \& Dryer (2008) defined it as the ability to feel good in life and make life cheerful even when choices are limited or unfavourable.

According to Amran (2007) Meaning is one of the seven spiritual dimensions that refers to the ability to find a sense of purpose, objective in everyday activities which includes pain and suffering. It is important to insert 'meaningful' to daily task as it increases creativity, productivity, motivation, efficiency and overall well being (Amabile \& Kramer, 2012). Amran \& Dryer (2008) further divides Meaning into two categories: Purpose and Service. Purpose is defined as a sense of goal that creates value and also determination. Purpose in this category is evaluated by these five items: i) the ability to view and implement daily responsibility religiously; ii) the ability to align my purpose for the greater good; iii) the ability to place financial benefit outside the primary goal; iv) the ability to do a good job without hoping for career advancement; and v) the ability to embrace pain and suffering and make sense out of them (Amran \& Dryer, 2008). Service is an act of assistance, help or aid. In the Spiritual Intelligence dimension, it is evaluated by the ability to feel passion in work, align it with the greater purpose (goal) and the ability to give assistance and benefit a larger society with daily work (activities) (Amran \& Dryer, 2008).

Willsey (2003) described Transcendence as otherness that differentiates every individual apart. One is not another, nor one is an extension of others. Dembski (2003) explained the origin of Transcendence from a Latin word which means to go beyond or climb over. It is the ability to surpass or excel oneself and reach a greater limit. According to Walsh and Vaughan (1993), selftranscendence is the root of Abraham Maslow's transpersonal psychology. It is formed from three main components: selfforgetfulness, transpersonal identification, and mysticism (Hamer, 2004).

According to Hamer (2004) selftranscendence is influenced by monoamines (also known as "God Gene"). The three major monoamines are serotonin (responsible for heightening sociability, change perception, and affect mood), dopamine (responsible in creating state 'mood' of excellence) and norepinephrine (responsible in reacting to stress by enhancing alertness). VMAT2 is an agent that transports the monoamines. Without VMAT2, monoamines will be reduced and cause one to have no interest in live, leading to death. Hence, Hamer's God gene proved not only plays a role in spirituality but also is an immensely important component of life.

Amran \& Dryer (2008) categorized transcendence into five characteristics: Higher-self, Holism, Practice, Relatedness, and Sacredness. Higher-self is often thought as an illusion of one that would have better judgment (Miller, 1978; Pierrakos, 1996; Roads, n.d.). The figure of God is also often used. Amran \& Dryer (2008) defined higherself as the ability to have faith is facing daily challenges by listening to the inner voice. It is also the ability to vision goals and purpose beyond extraordinary.

Holism is described as the application of a point of view where wholeness, unity and interconnection are found among diversification and differentiation (Amran, 2007). Bloom (2005) also mentioned that Holism in modern society is very much used in healthcare, education and politics to add in a humane touch. It can be evaluated by the ability to take in consideration a larger view and gain insight from daily obstacles, ability to combine or relates things (such as thought, situation, events and ideas), the ability to be a part of a greater society, and the ability to extract more insight from daily challenges by 
accepting life to have ups and downs (Amran \& Dryer, 2008).

Practice is defined as the effort of habitual or customarily used method to develop and enhance Consciousness or spiritual qualities (Amran, 2007). For example, performing meditation or prayers, drawing positive energy to face daily challenges; learn and adapt to histories, teachings, quotes to overcome obstacles; create inner and outer tranquility to accept more creative insight; look back to evaluate self's actions and recharge for a better future; performing traditional beliefs in time of transition; and use physical material to feel close to what is sacred (Amran \& Dryer, 2008).

Relatedness is the feeling of connection with others. Amran \& Dryer (2008) defined Relatedness through ability of heightening others awareness and point of view to a greater level, increase one's effectiveness through networking and also humble acceptance of inputs, and connects with others through compassion. Sacredness is the ability to live in conjunction with nature's gift, energy and essence (Amran, 2007). Amran \& Dryer (2008) listed a few items that can be used to evaluate sacredness. These include; i) the ability to experience out-ofoneself, grace, or overwhelming inspiration that gives insight or direction to face daily challenges; ii) the ability to express inner life force in the real world; iii) the ability to embrace a larger force than self and response effortlessly and spontaneously; and iv) the ability to heighten observation and take note of indescribable feelings or spiritual events.

In Amran's (2007) Spiritual Intelligence, he quoted Truth to be the ability to live with open acceptance, curiosity and cherish all creation. Amran \& Dryer (2008) later gathered six characteristic to define Truth, namely: Egolessness, Equantinimity, Innerwholeness, Openness, Presence and Trust.

Egolessness is the ability to be release self from adopted character and stay humble, cease resistance towards what wants and has to happen. In the Buddhist theory of Egolessness, it relates to the theory of 'NoSoul', or 'No-Self', or 'Non-Substantiality', or 'No-Entity' (Gnanarama, 2000). Amran \& Dryer (2008) listed three evaluation points to be Egolessness: i) the ability focus on other's flaws (reversed scored); ii) the want to be treated special (reversed scored); and iii) the mentality of emphasizing on being right (reversed scored).

Young (n.d.) defined Equanimity as inter-self balance that comes naturally without disturbance or intervention. Equanimity is what that allows one to feel and reach to the external forces, it is the opposite of suppression. Young (n.d.) also categorized Equanimity as the synonym to love. Amran \& Dryer (2008) categorized Equanimity as the ability to take control of one's emotion even when situation goes out of hand.

Inner-wholeness is defined as the ability to accept one as what one is regardless of all the shortcomings or incapacity. It is an ability to feel confident on oneself and acceptance of what one is (Amran \& Dryer, 2008). It is a total wellbeing that includes mental, physical, emotional, financial, relational and existential wholeness (Nielsen, n.d.). Openness relates to the ability to remain open heart and mind (positive attitude) towards all creation, knowledge, culture, wisdom, and so on. Kidd and Kidd (1994) described human's capability to listen and respond to a request is the cause of openness. It is the ability to be curious and poise a positive attitude to all that is not familiar. Amran \& Dryer (2008) listed a few character that evaluates openness of one: i) ability to accept unfavourable events; ii) ability to forgive those who have misunderstood oneself; iii) ability to remain calm and compose under uncertain situation; and iv) ability to overcome unpleasant experience with an open heart.

Presence is very much related to the amount of effort given to support actions in either 
virtual or real world (Zahorik \& Jenison, 1998). It answers the notion of "being here". Amran \& Dryer (2008) summarized Presence as the ability to focus on what that is happening/going on now (present) in order to achieve what that was fixed upon. It is important to be focused on now instead of drooling over the past or future. Trust is defined as the ability to stay hopeful and optimistic based on faith or believing (Amran, 2007). Adapted from McKnight and Chervany (1996/2000), they quoted ". . . trust is a term with many meanings." McKnight and Chervany (2000) also quoted that Trust is an important tool to create a positive interpersonal relationship because it decides how interactions with others are formed. It is also an important component to have an effective working environment.

\section{Methodology}

The dependent variables are Transformational leadership and transactional leadership, representing the leadership styles displayed by the student leaders. Meanwhile, independent variable consists of the five dimensions of spiritual intelligence: consciousness, grace, meaning, transcendence, and truth.

\section{SPIRITUAL INTELLIGENCE}

\section{TYPES OF STUDENT} LEADERSHIP

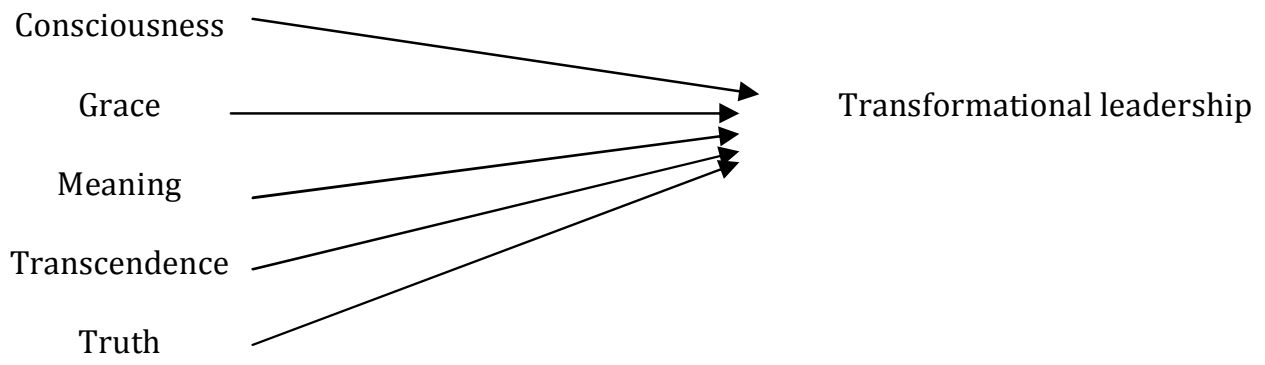

Figure 1: Research Framework

Based on the framework, the following hypotheses were developed:

$\mathrm{H}_{1}$ : There is no correlation between Consciousness and Transformational Leadership.

$\mathrm{H}_{2}$ : There is no correlation between Grace and Transformational Leadership.

$\mathrm{H}_{3}$ : There is no correlation between Meaning and Transformational Leadership.

$\mathrm{H}_{4}$ : There is no correlation between Transcendence and Transformational Leadership.

$\mathrm{H}_{5}$ : There is no correlation between Truth and Transformational Leadership.
A quantitative research approach has been used for data collection in this research. Respondents will be selected based on the fact that they have participated in leadership roles during academic year. A questionnaire formulated from the Multifactor Leadership Questionnaire (MLQ) and Integrated Spiritual Intelligence Scale (ISIS) framework will be distributed to this qualified sample group. The questionnaire is separated into two parts: Part A, Part B and Part C.

Part A focuses on demographic questions. The objective of Part A is to understand the background of respondent and categorize them accordingly. Part B consist of 21 question adopted from the Multifactor Leadership Questionnaire by Bass \& Avolio (1992). In this part, leadership traits (Transformational or Transactional) will be 
tested. Part $\mathrm{C}$ of the questionnaire adapted 44 questions from the Integrated Spiritual Intelligence Scale (ISIS) framework by Amran \& Dryer (2008). The objective of this section is to test the availability and strength of each Spiritual Intelligence traits in student leaders. Part A is represented in multiple choice questions while Part B and C uses Likert scale measurement of 1-6 (strongly disagree to strongly agree).

The sample group for this research is targeted towards student leaders undergoing their tertiary education. Areas of sample group leadership are not constrained. Student leaders may be a class representative, club leader, assignment group leaders and any other field that they took part in (in or out campus activities). A total of 200 student leaders were involved in the study. The questionnaire took about 20 minutes to complete.

\section{Descriptive Analysis}

As shown in Table 2, 77\% of the respondents belonged to the age group 21 to 25 . A majority of them are undergraduate students. Only $3 \%$ are aged above $31,9 \%$ from aged group 26 to 30 and $11 \%$ from age group 18 to 20 . $54.5 \%$ of them are females. $96 \%$ of them are single.

Table 2: Demographic Profile of the Respondents

\begin{tabular}{|c|c|c|c|}
\hline Variables & & Frequency & Percentage \\
\hline \multirow[t]{3}{*}{ Gender } & Male & 91 & 45.5 \\
\hline & Female & 109 & 54.5 \\
\hline & Total & 200 & 100.0 \\
\hline \multirow[t]{5}{*}{ Age } & $18-20$ & 23 & 11.5 \\
\hline & $21-25$ & 155 & 77.5 \\
\hline & $26-30$ & 17 & 8.5 \\
\hline & $>31$ & 5 & 2.5 \\
\hline & Total & 200 & 100.0 \\
\hline \multirow[t]{3}{*}{ Marital Status } & Single & 192 & 96.0 \\
\hline & Married & 8 & 4.0 \\
\hline & Total & 200 & 100.0 \\
\hline \multirow[t]{7}{*}{ Leadership Strength } & Very Weak & 2 & 1.0 \\
\hline & Weak & 13 & 6.5 \\
\hline & Somewhat Weak & 35 & 17.5 \\
\hline & Somewhat Strong & 83 & 41.5 \\
\hline & Strong & 47 & 23.5 \\
\hline & Very Strong & 20 & 10.0 \\
\hline & Total & 200 & 100.0 \\
\hline \multirow[t]{12}{*}{ Country } & Australia & 32 & 16.0 \\
\hline & Canada & 11 & 5.5 \\
\hline & China & 2 & 1.0 \\
\hline & Germany & 4 & 2.0 \\
\hline & Indonesia & 4 & 2.0 \\
\hline & Iran & 16 & 8.0 \\
\hline & Malaysia & 57 & 28.5 \\
\hline & Singapore & 47 & 23.5 \\
\hline & Taiwan & 8 & 4.0 \\
\hline & USA & 14 & 7.0 \\
\hline & Yemen & 5 & 2.5 \\
\hline & Total & 200 & 100.0 \\
\hline
\end{tabular}


As seen in Table 2, in terms of the respondents' self evaluation of their leadership skills, a majority $(41.5 \%$ or 83 entries) of them rated 'Somewhat Strong' while only $10 \%$ (20 entries out of 200 ) of the respondents expressed that they have 'Very Strong' leadership strength.

Table 3: Reliability Values

\begin{tabular}{|l|c|c|}
\hline Variables & No. & Alpha Value \\
\hline Consciousness & 6 & 0.441 \\
\hline Grace & 12 & 0.663 \\
\hline Meaning & 4 & 0.542 \\
\hline Transcendence & 10 & 0.630 \\
\hline Truth & 12 & 0.542 \\
\hline $\begin{array}{l}\text { Transactional Leadership } \\
\text { style }\end{array}$ & 10 & 0.730 \\
\hline $\begin{array}{l}\text { Transformational } \\
\text { Leadership style }\end{array}$ & 11 & 0.653 \\
\hline
\end{tabular}

The Cronbach alpha is used to test the internal reliability of the items. According to Sproles and Kendall (1986), Cronbach alpha coefficients of 0.4 or higher are considered acceptable. Reliability is the ability of a tool to measure a concept in a consistent manner, and it can be assessed in various ways; therefore, researchers distinguish among "test-retest" reliability, "intrarater" and "interrater" reliability, and "internal consistency" (Hinton, 2004). In this analysis, the variables have been found to be reliable. This is seen in Table 3.

\section{Findings and Discussion}

Based on the correlation analysis, all of the hypotheses were found to have a positive and significant relationship. This is seen in Table 4. With a Pearson Correlation coefficient value of 0.375 , shows that Consciousness has a low moderate strength with Transformational Leadership. However, if Consciousness is tested against Transactional Leadership, the correlation of coefficient shows an even lower degree of correlation. Consciousness is the defined as the ability of awareness and self knowledge (Amran, 2007). Hacker (2005) defined Consciousness as the core of Transformational Leadership as it led leader and followers into an open awareness of purpose and goal of the union. Simone (2012) had suggested the need to heighten the level of thinking in order to solve problems. In order to increase level of intelligence, it is important for leaders to raise consciousness through integration and interaction. As such, the findings agree with Hacker (2005).

As for Grace, the Pearson Correlation of Coefficient value shows a slightly higher value in Transactional Leadership as compared to the Transformational Leadership. According to Amran and Dryer (2008), Grace is the ability to appreciate, stays true to one's values, enjoys and be creative in daily tasks. It is very much related to relationship building. Weiner, Russell, \& Lerman (1979) and Veisson (1999) suggested that Grace is related to interpersonal appreciation for the contribution of other. It is also proven to help the organization to succeed where benefits of employees are emphasis and well taken care of.

The Pearson Correlation Coefficient for Meaning is 0.317 in relation to Transformational Leadership. This shows a moderate relationship between the two variables. Meaning is defined as the ability to perform tasks with purpose and passion 
(service) (Amran and Dryer, 2008). This is an important factor as in order to transform someone, purpose and passion is the core to have determination and focus. A low value in the relationship indicates that the student leaders lack the passion and the true meaning of performing the tasks. As such, the other team members are not "transformed" and do not feel the passion of the leader.

The level of influence of Transcendence to Transformational Leadership is relatively moderate to high with a Pearson Correlation value of 0.515 . Transcendence is an ability to perform beyond oneself while remain close to one's core value. The value shows that the student leaders are able to perform beyond their usual self and still remain to their basic values.

The Pearson Correlation value of Truth and Transformational Leadership is 0.416 . This is a moderate to high value. Truth is described as the ability to live with open acceptance, curiosity and cherish all creation (Amran, 2007). Morton (2012) defined Truth to coexist with love. He commented that with the absence of Truth and love, even the greatest leadership would be defeated. Transformational leaders are people who aim to provide a greater good for the society. Hence, it is only true that they embody the benefits of truth and love. In the case of the student leaders, they are able to accept the truth but only to a certain level as the coefficient value is 0.416 which shows a moderate to high value. Also, there is not much of open acceptance. The student leaders may not totally agree with the suggestions of their other team members.

Table 4: Correlational Values of Transformational Leadership and the Dimensions of Spiritual Intelligence

\begin{tabular}{|c|c|c|c|c|c|c|}
\hline \multicolumn{2}{|c|}{ Transformational } & Consciousness & Grace & Meaning & Transcendence & Truth \\
\hline & $\begin{array}{l}\text { Pears } \\
\text { on } \\
\text { Correl } \\
\text { ation } \\
\text { Sig. } \\
\text { (2- } \\
\text { tailed) } \\
\mathrm{N}\end{array}$ & $\begin{array}{l}.000 \\
200\end{array}$ & $\begin{array}{l}.561 \\
.000 \\
200\end{array}$ & $\begin{array}{r}.317 \\
.000 \\
200\end{array}$ & $\begin{array}{l}.515 \\
.000 \\
200\end{array}$ & $\begin{array}{l}.000 \\
200\end{array}$ \\
\hline Hypothesis & & $\mathrm{H} 1$ & $\mathrm{H} 2$ & H3 & $\mathrm{H} 4$ & H5 \\
\hline Results & & $\begin{array}{l}\text { Positive and } \\
\text { Significant }\end{array}$ & $\begin{array}{l}\text { Positive } \\
\text { and } \\
\text { Significant }\end{array}$ & $\begin{array}{l}\text { Positive } \\
\text { and } \\
\text { Significant }\end{array}$ & $\begin{array}{l}\text { Positive and } \\
\text { Significant }\end{array}$ & $\begin{array}{l}\text { Positive } \\
\text { and } \\
\text { Significant }\end{array}$ \\
\hline
\end{tabular}

\section{Conclusion and Area of Future Study}

The purpose of the study was to examine the relationship of Spiritual Intelligence and transformational leadership among student leaders. It was found that the dimensions of Spiritual Intelligence have a positive and significant correlation with Transformational
Leadership. However based on the coefficient values, it showed that the student leaders are not fully transformed. They do not display the full characteristics of Spiritual Intelligence. It was found that among the dimensions, Grace has the highest correlation value. It is suggested that for future research, the study would also involved more students 
from other parts of the world. Having a larger sample size would also improve the reliability of the results and provide an even deeper insight to the subject matter. As claimed by Dougherty (2011), empirical research on the topic is rather limited and therefore more studies could be taken to improve the knowledge and understanding of the matter.

\section{Acknowledgment}

The author(s) would like to acknowledge the assistance of the people involved in the distribution of the survey forms.

\section{References}

Amabile, T. \& Kramer, S. (2012). "How Leaders Kill Meaning at Work," The McKinsey Quarterly, 2012 Issue \#1, 124-131.

Amram, Y. (2007). "The Seven Dimensions of Spiritual Intelligence: An Ecumenical, Grounded Theory," Available at: http://www.yosiamram.net/docs/7_Dimensi ons_of_SI_APA_confr_paper_Yosi_Amram.pdf

Amram, Y. \& Dryer, C. (2008). "The Integrated Spiritual Intelligence Scale (ISIS): Development and Preliminary Validation,"

Animasahun, R. A. (2010). "Intelligent Quotient, Emotional Intelligence and Spiritual Intelligence as Correlates of Prison Adjustment among Inmates in Nigeria Prisons," Journal of Social Science, 22(2): 121128 (2010)

Avolio, B. J., Bass, B. M. \& Jung, D. I. (1999). "Re-examining the Components of Transformational and Transactional Leadership Using the Multifactor Leadership Questionnaire," Journal of Occupational \& Organizational Psychology, 72, 441-462.

Avolio, B. J., Waldman, D. A. \& Yammarino, F. J. (1991). "Leading in the 1990s: The Four I's of Transformational Leadership," Journal of European Industrial Training, Vol. 15 Iss: 4
Banerji, P. \& Krishnan, V. R. (2000). "Ethical Preferences of Transformational Leaders: An Empirical Investigation," Leadership \& Organization Development Journal, Vol. 21 Iss: 8, pp.405 - 413

Barnett, K., McCormick, J. \& Conners, R. (2001). "Transformational Leadership in Schools-Panacea, Placebo or Problem?," Journal of Educational Administration 39, No 1: 24-46.

Basham, L. M. (2010). "Transformational and Transactional Leaders in Higher Education," International Review of Business Research Papers Volume 6. Number 6. December 2010 Pp.141 -152.

Bass, B. M. (1985). 'Leadership and Performance beyond Expectation,' New York Free Press.

Bass, B. M. (1999). “Two Decades of Research and Development in Transformational Leadership," European Journal of Work and Organizational Psychology, 8 (1), 9-32.

Bass, B. M. \& Avolio, B. J. (1997). 'Full Range Leadership Development: Manual for the Multifactor Leadership Questionnaire,' Palo Alto, CA: Mindgarden.

Bass, B. M. \& Steidlmeier, P. (2003). "Ethics, Character, and Authentic Transformational Leadership Behaviour," Available at: http://web.sau.edu/RichardsRandyL/ETHIC S\%20MORAL\%20CHARACTER\%20AND\%20 AUTHENTIC\%20TRANSFORMATIONAL\%20 LEADERSHIP.pdf

Bjurström, E. (2012). "Minding the Contexts of Mindfulness in Quality Management," International Journal of Quality \& Reliability Management, Vol. 29 Iss: 6 pp. $699-713$.

Bloom, W. (2005). 'Holism,' European Business Review, Vol. 17 Iss: 1, pp. 
Bono, J. E. \& Judge, T. A. (2004). "Personality and Transformational and Transactional Leadership: A Meta-Analysis," Journal of Applied Psychology 2004, Vol. 89, No. 5, 901910.

Burns, J. M. (1978). 'Leadership,' New York: Harper \& Row

Caldwell, C., Dixon, R., Floyd, L., Chaudoin, J., Post, J. \& Cheokas, G. (2011). 'Transformative Leadership: Achieving Unparalleled Excellence,'

Chalmers, D. J. (2002). “Consciousness and its Place in Nature," Available at: consc.net/papers/nature.html

Connor, L. J. (2004). "Moving from Transactional to Transformational Leadership in Colleges of Agriculture," NACTA Journal, 52-56.

Corrigan, P. W. \& Garman, A. N. (1999). "Transformational and Transactional Leadership Skills for Mental Health Teams," Community Mental Health Journal, vol. 35, no. 4, pp. 301-312

Dembski, W. A. (2003). "Transcendence (Entry for New Dictionary of Christian Apologetics)," Available at: http://www.designinference.com/document s/2003.10.Transcendence_NDOCApol.pdf

Dollak, A. R. (2008). "Transactional Leadership vs. Transformational Leadership," Retrieved June 22, 2009 from http://www.associatedcontent.com.

Dougherty, T. J. (2011). "The Relationship between Spirituality, Spiritual Intelligence, and Leadership Practices in Student Leaders in the BYU-Idaho Student Activities Program,"
Emmons, R. A. (2000). "Is Spirituality an Intelligence? Motivation, Cognition, and the Psychology of Ultimate Concern," The International Journal for the Psychology of Religion, 10(1), 3-26

Emmons, R. A. \& McCullough, M. E. (2003). "Counting Blessings versus Burdens: An Experimental Investigation of Gratitude and Subjective Well-Being in Daily Life," Journal of Personality and Social Psychology, Vol 84(2), Feb 2003, 377-389 (2003).

Gnanarama, P. (2000). "Essentials of Buddhism," Available at: http://www.buddhanet.net/pdf_file/essentia lsof.pdf

Hacker, S. K. (2005). "Transformational Leadership: Creating Step-Functional Change," Available at: http://www.eoq.org/fileadmin/user_upload /Documents/Congress_proceedings/Turkey_ 2005/Proceedings/048

_Stephen_Hacker.pdf

Hamer, D. (2004). "The God Gene How Faith is Hardwired into Our Genes," New York: Doubleday. Pages 211-12

Hanna, R. (2011). "Kant's Biological Theory of Freedom," Available at: http://www.colorado.edu/philosophy/paper _hanna_kant $\% 27$ s_biological_theory_of_freed om_march11.pdf

Hinton, P. R. (2004). Statistics Explained, 2nd ed. London: Routledge

IPlan (2011). "The Importance of Student Leadership," February2, 2011. Retrieved from

http://www.iplanmagazine.com/?p=267 
Kent, T. W., Crotts, J. C. \& Azziz, A. (2001). "Four Factors of Transformational Leadership Behaviour," Leadership and Business Development Journal, Vol. 22 No. 5, pp. 221-229.

Kidd, S. D. \& Kidd, J. W. (1994). "Truth, Openness and Humility," Available at: http://www.inbetweenness.com/Sunnie's\% 20Publications/TRUTH,\%200PENNESS\%20 AND\%20HUMILITY.pdf

Langlois, J. H., Kalakanis, L., Rubenstein, A. J., Larson, A., Hallam, M. \& Smoot, M. (2000). "Maxims or Myths of Beauty? A Meta-Analytic and Theoretical Review," Psychological Bulletin 2000, Vol. 126, No. 3, 390-423.

Miller, S. (1978). "Dialogue with the Higher Self," Synthesis, Vol. 1, no. 2 1975, pp. 122139.

McDowell, J. H. (1995). "Immanence and Immanent Truth," Oral Tradition, 10/2 (1995): 235-262

McKnight, D. \& Chervany, N. (1996). 'The Meaning of Trust,' Available at: http://misrc.umn.edu/wpaper/WorkingPap ers/9604.pdf

McKnight, D. H. \& Chervany, N. L. (2000). "Trust and Distrust Definitions: One Bite at a Time," Available at: https://www.msu.edu/ mcknig26/Trust\%2 0and\%20Distrust\%20Definitions.pdf

Morgan, G. (1997). "Images of Organization," San Francisco: Berrett-Koehler.

Morton, J. (2012). "Transformational Leadership: Leading in Love and Truth," Available at: http://www.msia.org/newdayherald/archiv es/2603-what-is-transformationalleadership

Nielsen, A. (n.d.). “The Miracle of Wholeness," Available at: http://purduenielsen.com/pdf/TheMiracleof Wholeness.pdf
Patton, J. R. (2003)."Intuition in Decisions," Management Decision, Vol. 41 Iss: 10 pp. 989 - 996

Pierrakos, E. B. (1996). "The Higher Self, the Lower Self, and the Mask," The Pathwork Foundation (1996 Edition). Available at: www.pathwork.org/lectures/P014.PDF

Podsakoff, P. M., MacKenzie, S. B., Moorman, R. H. \& Fetter, R. (1990). "Transformational Leader Behaviours and their Effects on Followers' Trust in Leader, Satisfaction, and Organizational Citizenship Behaviours," Leadership Quarterly, 1, 107-142.

Rebel, R., Schwarz, N. \& Winkielman, P. (2004). "Processing Fluency and Aesthetic Pleasure: Is Beauty in the Perceiver's Processing Experience?," Personality and Social Psychology Review 2004, Vol 8, No. 4, 364-382.

Roads, M. J. (n.d.). (20130. "The Difference between Soul, Spirit and Higher Self," Available at: http://www.michaelroads.com/teachings/1articles-by-michael/31-the-differencebetween-soul-spirit-and-higher-self.html

Schaeffer, P. V. (2008). "Thoughts Concerning the Economic Valuation of Landscapes," Journal of Environmental Management. 89, 146-154.

Simone, R. L. (2012). "Transformational Leadership," Central New York Business Journal. Available at: http://discoverpls.com/images/news/transf ormational_leadership.pdf

Sproles, G. B. \& Kendall, E. L. (1986). “A Methodology of Profiling Consumers' Decision Making Styles," Journal of Consumer Affairs, 20(2) 267-279

Sundgren, M. \& Styhre, A. (2004). "Intuition and Pharmaceutical Research: The Case of AstraZeneca," European Journal of Innovation Management, Vol. 7 Iss: 4 pp. 267 - 279 
Swarup, A. (2010). "The Role of Eastern Wisdom and Spiritual Intelligence for Dignity and Humiliation: A Road Map to the Future," Available at: http://www.humiliationstudies.org/docume nts/SwarupNY10meeting.pdf

Traüffer, H. C. V., Bekker, C., Bocârnea, M., \& Winston, B. E. (2010). "A Three-Factor Measure of Discernment," Leadership \& Organization Development Journal, Vol. 31 Iss: 3 pp. $263-284$

Vaughan, F. (2002). "What is Spiritual Intelligence?," Journal of Humanistic Psychology, Vol 42, No. 2. Spring 2002, 16-33.

Veisson, M. (1999). "Depression Symptoms and Emotional States in Parents of Disabled and Non-Disabled Children," Social Behavior and Personality, 27, 87-98.

Velman, M. (2009). "How to Define Consciousness- and How not to Define Consciousness," Journal of Consciousness Studies, 16(5), 2009, pp 139-156

Walsh, R. \& Vaughan, F. (Eds.).(1993). Paths beyond Ego: The Transpersonal Vision, Los Angeles: .1. P. Tarcher/Putnam.

Weiner, B., Russell, D. \& Lerman, D. (1979). "The Cognition-Emotion Process in Achievement-Related Contexts," Journal of Personality and Social Psychology, 37, 1211-1220.

Wigglesworth, C. (2002). "Spiritual Intelligence and Why It Matters," Available at:

http://www.deepchange.com/system/docs/ 9/original/Spiritual\%20Intelligence $\% 20 \& \%$ 20Emotional\%20Intelligence\%202011 .pdf?1311106142

Wigglesworth, C. (2003). "Spiritual Intelligence: What is it? How can we Measure it? Why would Business Care?," Available at: http://www.kpokorny.com/content/user_fil es/spiritual_intelligence-what_is_it.pdf
Wigglesworth, C. (2006). "Why Spiritual Intelligence Is Essential to Mature Leadership," Available at: http://www.deepchange.com/system/docs/ 8/original/Spiritual-Intelligence-n-Matureleadership.pdf?1311106089

Willsey, J. K. (2003). "Recovering Transcendence and Immanence," Available at: http://app.razorplanet.com/acct/414710233/resources/ppub_willseyrecovering_transcendence_and_immanence.p $\mathrm{df}$

Wood, A. M., Froh, J. J. \& Geraghty, A. W. A. (2010). "Gratitude and Well-Being: A Review and Theoretical Integration," Clinical Psychology Review, 30, 890-905.

Young, S. (n.d.) "What is Equanimity?," Available at: www.shinzen.org/Retreat\%20Reading/artE quanimity.pdf

Yukl, G. A. (2006). Leadership in Organizations, (6th ed.). Upper Saddle River, NJ: Pearson-Prentice Hall.

Zahorik, P. \& Jenison, R. L. (1998). "Presence as Being-in-the-World," Massachusetts Institute of Technology, Presence, Vol. 7, No. 1, February 1998, 78-89

Zohar, D. (2010). "Exploring Spiritual Capital: An Interview with Danah Zohar," Newsletter. Volume 5, Issue 5. Available at: http://spirituality.ucla.edu/docs/newsletter s/5/Issue_5/Zohar_Final.pdf

Zohar, D. \& Berman, M. (2001). 'Developing Spiritual Intelligence through ELT,' Paper presented at the Brighton IATEFI Conference.

Zohar, D. \& Marshall, I. (2000). 'SQ: Spiritual Intelligence, the Ultimate Intelligence,' New York: Bloomsbury Publishing. 